\title{
Universidade - até quando resistir?
}

A crise das Universidades Públicas Brasileiras vem se acentuando sem que a sociedade tenha consciência plena dos riscos que passamos com a sua possivel extinção ou mesmo sua desqualificação.

Detentora dos melhores e maiores quadros docentes do país, estas universidades romperam obstáculos e se constituiram em centros de saber de muitas áreas do conhecimento, tornaram-se modelos e sede de muitos grupos de excelência de ensino e pesquisa.

O que se tem hoje năo foi fruto do acaso, mas resultado de anos de compromisso ético e responsável das pessoas que estimularam, capacitaram e organizaram este significativo contingente de intelectuais. Persistência, coragem e audácia foram companheiras permanentes nesta viagem, mesmo sob os mais de vinte anos de regime ditatorial, com grande censura aos conteúdos veiculados nos meios de comunicaçăo e repressões às manifestações culturais e políticas. Neste periodo viveu-se experiências amargas, onde o livre pensar foi submetido a formas atrozes de tortura. Raciocinar sobre o momento que se vivia era desestimulador, falar sobre ele era estar sob a mira vigilante dos patrulhadores de idéias, organizar-se em grupos de discussão era assumir os riscos de sua permanência no país ou mesmo perder as imunidades necessárias à sobrevivência.

Embora questionada, invadida, devassada, esta instituição manteve-se de pé por tudo que ela representava para o crescimento intelectual estratégico desta nação. Muitos dos cérebros exilados impuseram o seu conhecimento $e$ as suas experiências junto aos intelectuais do primeiro mundo.

Revisitando o passado, verifica-se que a formaçăo de pós-graduação "stricto sensu" dos brasileiros foi feita no exterior, às custas do próprio investimento nacional (bolsas do CNPq e outras). Só mais tarde criamos os nossos cursos, os quais cresceram expressivamente nas décadas de 80 e 90 . Decorrente desta 
iniciativa, verifica-se a crescente produção cientifica gerada nestes anos, com o aumento das publicações.

Apesar do acúmulo de saberes e experiência desenvolvidos ao longo de sua história, hoje esta instituição vem sendo tratada como um fardo nas contas públicas. Sofre, igualmente e sem diferenciações, o tratamento econômico da restrição de verbas e as ações da implantação do estado mínimo desenvolvido pelo atual governo. A estagnação dos salários por mais de três anos, o estímulo à aposentadoria, a redução de bolsas e a destinação dos recursos dos órgăos educacionais para outros fins e outros atores (por exemplo, as organizações não governamentais - ONG(s)) têm minado a potência das Universidades naquilo que determina a sua força de impulsão, os seus cérebros.

Esvaziando-se, acentuada ou gradativamente, vemos diluir-se um patrimônio cultural construído por tantas lutas e dedicações anônimas de cada departamento, de cada Universidade, sem uma razão aparente que justifique o propósito das atuais ações de governo.

O descontentamento cresce no seio do corpo social das universidades, a insatisfação cresce entre os pesquisadores, enfim a pressão aumenta sob justificativas variadas, o governo desqualifica o ensino público, mesmo quando os resultados do Provão imposto demonstram o contrário. Por outro lado, aumenta a intolerância dos pressionados para o diálogo.

Creio que estamos prestes a entrar numa crise sem precedentes no setor. Penso que muita poeira velha deverá ser limpa no sistema de ensino público. De fato, precisamos nos renovar para enfrentar os novos tempos. Mas não será de forma autoritária que o governo conseguirá o melhor. $\mathrm{O}$ diálogo não pode ser fruto da arrogância de um e da intolerância do outro. $O$ resultado de um trabalho aberto e sem idéias pré-concebidas de ambos trará o melhor para a sociedade que nos sustenta.

Maria Therezinha Nóbrega da Silva 